https://doi.org/10.25143/socr.18.2020.3.147-154

\title{
Trade War: Georgia vs. Russia
}

\author{
Ph.D. candidate Giga Abuseridze \\ Rīga Stradiñš University, Faculty of Law \\ gabuseridze@mfa.gov.g
}

\begin{abstract}
The following article focuses on the history of trade relations between Georgia and Russia that in the Author's view eventually developed into the "trade war". Enrolment of Russia into the WTO enabled subjection of Russia to the WTO regulations. Georgia, as a full member of the WTO, rather legitimately refused to allow Russia to join the organisation until Moscow would fulfil Tbilisi's claims. One of the demands of the Georgian side was directly related to the separatist conflicts in Abkhazia and South Ossetia, which further complicated the negotiations due to the destructive actions of Russia. There are difficult issues connected to the Georgian position from the global trade perspective. The position deals with the legally political difficulties. The article provides insight into the problem regarding the Trade War from the Georgia perspective.
\end{abstract}

Keywords: trade war, World Trade Organisation, International Monitoring System, Deep and Comprehensive Free Trade Agreement, Regional Trade Agreement.

\section{Introduction}

Negotiations between Georgia and Russia on joining the WTO have a long history. Georgia's position on Russia's accession to the WTO has always been determined by the political situation between the two countries. Russia had been negotiating membership in the organisation for almost 18 years [1].

Georgia, as a full member of the WTO, rather legitimately refused to allow Russia to join the organisation until Moscow would fulfil Tbilisi's claims. One of the demands of the Georgian side was directly related to the separatist conflicts in Abkhazia and South Ossetia, which further complicated the negotiations due to the destructive actions of Russia.

Negotiations on Russia's accession to the World Trade Organisation began in 2002. The first piece of information on this issue is an interview with the Russian President Vladimir Putin in June 2002, where he expressed his satisfaction that Russia's accession to 
the World Trade Organisation would facilitate trade around the world. At the same time, on December 5, 2002, the Georgian parliament adopted a resolution in which the Georgian government vetoed Russia's accession to the World Trade Organisation. After the Rose Revolution, in February 2004, when an attempt was made to mend relations with Russia, the Georgian parliament temporarily cancelled the veto. Nevertheless, the negotiations reached an impasse - the main task of the Georgian government was to place Georgian customs officers at the state border, but for 8 years the negotiations did not yield any results. Ultimately, as a result of the engagement of the US President, Georgia's interest elaborated in the following position - if Georgia cannot control freight flows along the GeorgianRussian state border, a foreign authoritative organisation should assume this function.

\section{Methods and materials}

In the article, the Author uses several general scientific methods as a method of analysis, discovering the regularities in the context of trade war, historical method, based on the analysis of the development of the research object, identifying the mechanisms of formal and informal legally political side, comparative method and several legal norm interpretation methods - grammatical method, analysing the legal regulation of trade issues, systemic interpretation method to establish the relationship between to parties involved in trade topic, as well as teleological interpretation method to clarify the meaning of legally political relations, and historical method, to clarify historical issues related to trade between Georgia and Russia.

\section{Prerequisites for concluding the Agreement}

According to the WTO rules, accession of a new country requires the approval of all member states. Georgia was one of the final obstacles for Russia to join the WTO. Georgia and Russian Federation had disagreement on border checkpoints of Roki and Gantiadi on the occupied territories. Georgia demanded clarification of their legal status and the right of monitoring. On November 2011, in Geneva, with the participation of Switzerland, Georgia and the Russian Federation agreed on having a neutral company monitor the movement of goods [2]. The Swiss Confederation was tasked with selecting a neutral private company in consultation with Georgia and the Russian Federation.

The Agreement does not mention any geographic names, only geographic coordinates. The Agreement establishes three trade corridors: Adler-Zugdidi; the village of Nar (North Ossetia) - Gori; and Kazbegi-Zemo Larsi [3]. All goods entering and exiting these corridors would be subjected to monitoring by the neutral private company. The parties agreed on creating a mechanism of customs administration and monitoring of trade in goods. The mechanism's functions included gathering and sharing of information, ensuring transparency, transferring data, preventing crime and smuggling, and examining suspicious cargo. Georgia and the Russian Federation decided that the mechanism 
would entail both Electronic Data Exchange System (EDES) and International Monitoring System (IMS) [4].

The Agreement between the Government of Georgia and the Government of the Russian Federation on the Basic Principles for a Mechanism of Customs Administration and Monitoring of Trade in Goods was signed on November 9, 2011. Based on Georgia's consent, the Russian Federation acceded to WTO and the Agreement entered into force on August 22, 2012. As stipulated by the Agreement, the Swiss Confederation selected the neutral company SGS Societe Generale de Surveillance SA for oversight functions. Georgia and Russia had to enter separately into the contract with the company [5].

The process of elaborating the contract took place in 2013-2014 with involvement of Switzerland. Representatives of SGS visited Georgia several times and after holding meetings, the initial version of the contract was elaborated. In 2015, a trilateral meeting of the Russian Federation, Georgia, and Switzerland with the participation of SGS representatives was held for the final review of the contract.

Apart from the contract, the parties reviewed two additional documents: Rules and Procedures (regulations) of a Joint Committee (body set up by the Agreement for discussing ongoing issues and settling disputes with involvement of a neutral party) and a Trust Fund document which established the rules for opening the bank account and transferring the reimbursement to SGS.

At the same time, Russia begins bilateral relations with the Abkhaz and Ossetian sides, concluding agreements with them that are incompatible with the Georgian legislation. Confronted with such behaviour of Russia, Georgia is forced to scrutinise the steps taken by Russia in order to identify additional threats. In December 2017, the Contract was signed between the Georgian side and the Swiss company SGS [6]. In response, Russia signed the Contract with the Swiss company in May 2018 and transferred the mandatory fee in June. Georgia transferred the fee in November. This ended the legal period of this dramatic story.

Negotiations between Georgia, Switzerland and Russia were held in February 2019, and the monitoring process was due to start in March 2020. However, the negotiation process was constantly dragged out. Georgia has the only option left, to force Russia to subject its cargo to monitoring.

\section{Russian "lessons" instead of trade neutrality}

In 2005, the Russian Federation launched a full-scale trade/economic blockade on Georgia. The Kremlin targeted the trading sector, which was most dependent on the Russian market at the time [7].

In December 2005, the Russian Federal Department of Veterinary and Phytosanitary banned the import of live plant products from Georgia to Russia with the pretence of violating the standards of microbiological composition. One month after this decision, on January 22, 2006, Georgia found itself in an energy blockade. The main gas pipeline 
exploded in the North Caucasus, all power plants were shut down, the electricity system could not withstand the load and as a result the entire country of Georgia experienced blackout for several days. After the energy blockade, Georgia decided to give up dependence on Russian natural gas; as a result, Russia practically lost its leverage of influence.

One month after the pipeline exploded in March 2006, Russia expanded its embargo and banned the export of wine from Georgia. For this period, $20 \%$ of total exports or $\$ 153$ million came on Russia. As a result of the blockade, exports halved in the first year. The embargo became a signal for Georgian entrepreneurs, and as a result of hard work, Russia's share in Georgian exports fell to $2 \%$.

After the revelation of Russian spies in Georgia, on October 6, 2006, a cargo plane landed at Tbilisi International Airport with hundreds of Georgian citizens expelled from Russia. A total of 4,634 citizens were deported then. On this fact, 13 years later, the European Court of Human Rights ordered Russia to pay multimillion-dollar compensation to the victims.

On October 2, 2006, the Russian Federation terminated postal, road, air, sea and rail connections with Georgia having violated the Convention on International Civil Aviation, as well as a number of bilateral and multilateral agreements with Georgia. The seven-year embargo ended in 2013, with exports to Russia quadrupling in 2013 and reaching \$ 396 million in 2018.

The Russian embargo made it clear that modern challenges in Georgia's trade relations required greater diversification in order to avoid and prevent potential threats in the future. Following the signing of the Deep and Comprehensive Free Trade Agreement (DCFTA) with the European Union, the export of Georgian products and their competitiveness in the world market became particularly important.

From 2014 to 2020, the volume of Georgia's trade with the EU shows that Georgia's trade relations with the EU are steadily growing and exceed the Georgian-Russian trade relations several times [8].

The action taken by the Russian Federation in 2005, from today's perspective, can be unequivocally interpreted as a trade war declared by Russia against Georgia, the main goal of which was to bring down the Georgian economy. In this case, too, Russia's main goal was to punish Georgia, which was motivated by political objectives. Three years after the start of the trade war, in 2008 Georgia fell victim to Russian intervention.

It should also be taken into consideration that Russia officially applied to the GATT in 1993 with the aim to join it. Negotiations for membership began in 1995, long before Georgia became a member of the World Trade Organisation. Then Russia's accession to the organisation was hampered by other factors. In addition to Georgia, Russia had been clarifying relations with the United States and EU countries. In 2009 in Davos, the Russian prime minister voiced his suspicion that Russia's membership in the organisation was obstructed due to political motives. The analysts attributed the delay to the authoritarian form of government in the Russian Federation as well as international statistics showing high levels of corruption, high annual bribery rate, shadow economy 
and government-controlled business. Nevertheless, the United States and the European Union could not deny and escape the fact that Russia's membership in the World Trade Organisation would be in their favour.

After joining the WTO, Russia became obliged to comply with international norms, while revoking a pre-existing specific import license or additional requirements that did not comply with the requirements of the trade organisation. Also, after Russia's accession to the WTO, importers to Russia would no longer need a license for products such as alcohol, wood and pharmaceuticals, and Russia could no longer impose additional requirements on them.

\section{Russia-Georgia Agreement: future threat or successful step}

One of the advantages of the Russia-Georgia Agreement is that Georgia has proved to the world that it is part of the civilised world and does not intend to create the world problems to prevent Russia from joining the WTO for the sake of its own private interests. This document is both a trade / economic and a political project for Georgia. It is the only document signed with Russia that implies Abkhazia and South Ossetia within Georgia, although they are not mentioned and are involved in the implementation of the Agreement. With this very Agreement, Russia indirectly confirms the territorial integrity of Georgia.

The Agreement establishes one important institution - a Joint Committee, which should discuss all possible problems. The Committee includes Georgia, Russia and Switzerland. It also must be highlighted that Abkhazia and Ossetia are not presented separately. According to the Author, this Committee can become an additional resource in the process of resolving the Russian-Georgia conflict. In general, the factor of Switzerland as a mediating state is extremely important. It is one of the leading countries in Europe although neither a member of the European Union nor of NATO due to its neutral status. Consequently, its involvement in the Georgian-Russian context brings new opportunities.

The Agreement establishes three trade corridors in the directions of Abkhazia and South Ossetia and on Lars, where cargo is currently being transported. The terminals of the Swiss company will be located on the Russian side in the cities of Adler, Vladikavkaz and Lars, on the Russian-Georgian state border, which in itself has a great political significance. The cargo will be transported only between Russia and Georgia, though the cargo may be destined to different countries such as Turkey, Armenia, Iran, etc.

Why did the third checkpoint Lars, which already exists, found itself in the Agreement? the Author considers this leaves Georgia in a politically advantageous situation, as it proves that the Agreement goes beyond the Russia-Georgia conflict and embraces broader perspectives. The document regulates trade between the two countries and the agreement also includes the current checkpoint, which, along with the other two terminals, fully covers Russian-Georgian road freight traffic. 
However, this Agreement contains one major drawback. In particular, only road freight is monitored under the Agreement between the parties. In addition to roads in Abkhazia, a significant amount of cargo flows through ships and railways, including equipment and weapons of Russian military bases. Cargo transported by sea and rail will not be subject to the monitoring provided for in the Agreement. As for the Tskhinvali corridor, there is only a road in this direction and in this case the cargo will be better inspected. Therefore, in the future Georgia should take serious steps to eliminate this shortcoming.

Another issue that can be assessed in a negative context is that the Swiss company does not have the so-called "Barrier right", i.e. it cannot check all the cargo. The company can inspect and fix only the cargo whose owner is interested in undergoing international monitoring. It should be important for the Georgian side to know what cargo remains on the territory of Abkhazia and South Ossetia. This is a task that must be fully implemented under this Agreement.

There is an important point that Russia can use to strengthen its positions: the Agreement confirms the parties to fight illegal trade. Georgia believes that Russia is trading illegally with the Abkhazian and Ossetian sides, and if the agreement obliges it to eliminate illegal trade, then Georgia may be required to legally recognise many of the actions it deemed illegal prior to the entry into force of the Agreement. Otherwise, Russia can argue with Georgia in both the Joint Committee and the Arbitration. Russia will claim that it provides information to the parties on what it is doing whereas Georgia considers it illegal trade. Russia may insist that it had signed this Agreement because it made the relations transparent and legitimate, and if Georgia considers everything illegal, it means that it only needs the document to reveal illegal cargo. If such a position is also agreed by the third neutral party - Switzerland, the remark provided from Switzerland will be accountable. Georgia should weigh up well when to evaluate this or that event as standing outside the law.

The third and a very important factor is that the world attitude towards Russia has changed significantly since 2011 due to the events in Crimea, Syria or Venezuela. Under the new circumstances, Russia may try to use this Agreement to legitimise the de facto authorities of Abkhazia and South Ossetia, or to promote the work of their socalled Customs or border guards. This means that due to Russia's unfavourable role in the world, the conclusion of this Agreement may provoke additional risks. The WTO, the EU, the UN and the OSCE should take care to make the implementation of this Agreement more effective.

\section{Conclusion}

If Georgia opens trade corridors on the basis of the Russian-Georgian Agreement of 2011, then it should do so in its own interests. The active support of Georgia and its allies, including the WTO, the European Union and the United Nations will be important 
in this process. As Georgia is confronted with such an aggressive and difficult player as Russia, it will depend on this very factor whether or not the implementation of this Agreement proves useful for the peace-making process.

The lifting of the embargo on Georgia by Russia was conditioned by the Agreement signed in 2011 on the basis of which Georgia agreed to Russia's accession to the WTO. Russia's accession to the World Trade Organisation (WTO) meant turning the country into a civilised framework and automatically implementing/enforcing WTO rules, which obliges the Russian Federation to adhere to the principles of the General Agreement on Tariffs and Trade (GATT) and the World Trade Organisation (WTO). The WTO membership was the very precondition for Russia to lift the embargo on Georgia on the basis of common regulations. The reason why Russia imposed embargo on Georgia should be considered. Incidentally the pretext for the embargo was the poor quality of the products while the World Trade Organisation refers to the export of quality products to the market.

\section{Tirdzniecības konflikts: Gruzija vs. Krievija}

\section{Kopsavilkums}

Gruzijas un Krievijas sarunām par iestāšanos Pasaules Tirdzniecības organizācijā ir sena vēsture. Gruzijas nostāju par Krievijas pievienošanos Pasaules Tirdzniecības organizācijai vienmēr ir noteikusi abu valstu politiski tiesiskā situācija. Gandrīz 18 gadus bija vērojama Krievijas ietekme attiecībā uz Gruzijas dalību attiecīgajā organizācijā. Jāatzīmē, ka Gruzija kā pilntiesīga Pasaules Tirdzniecības organizācijas dalībvalsts pilnīgi likumīgi pien̦ēma lēmumu atteikt Krievijas dalību tajā, vienlaikus lūdzot izpildìt Gruzijas prasības. Jāpiezīmē, ka viena no Gruzijas puses prasībām bija tieši saistīta ar separātiskajiem konfliktiem Abhāzijā un Dienvidosetijā, kas vēl vairāk sarežǵỉja sarunas Krievijas darbỉbas dēḷ.

Sarunas par Krievijas pievienošanos Pasaules Tirdzniecības organizācijai sākās 2002. gadā, un pārrunu laikā tika vērotas vairākas politiski tiesiska rakstura darbības, kas ietekmēja turpmāko attiecību scenāriju. Veiktais pētījums norāda uz to, ka gadījumā, ja Gruzija atver tirdzniecības koridorus, pamatojoties uz Krievijas un Gruzijas 2011. gada nolīgumu, tad valsts vispirms ievēro savas intereses. Šajā procesā ir svarīgs aktīvs Gruzijas un tās sabiedroto, tostarp Pasaules Tirdzniecības organizācijas, Eiropas Savienības un Apvienoto Nāciju Organizācijas, atbalsts. Jāatzīmē, ka Gruzijas noteiktā embargo atcelšanu Krievijai noteica 2011. gadā parakstītais nolīgums, uz kura pamata Gruzija piekrita Krievijas uzṇemšanai organizācijā.

Krievijas pievienošanās Pasaules Tirdzniecības organizācijai nozīmēja pārvērst valsti par civilizētu sistēmu un automātiski ieviest noteikumus, kas uzliek Krievijai pienākumu ievērot vispārējo vienošanos par tarifiem un tirdzniecību.

Atslēgvārdi: tirdzniecības konflikts, Gruzija un Krievija, Pasaules Tirdzniecības organizācija, brīvās tirdzniecības līgums, regiionālais tirdzniecības līgums. 


\section{References}

1. Internationally distributed American daily middle-market newspaper - "Russia joins WTO after 18 years of negotiations", published August 22, 2012. Available at http://usatoday30.usatoday. com/money/economy/trade/story/2012-08-22/russia-joins-world-trade-organization/57207664/1 [Accessed: July 30, 2020].

2. Leading EU affairs newspaper - New Europe "Russia and Georgia sign WTO agreement", published November 13, 2011. Available at https://www.neweurope.eu/article/russia-and-georgiasign-wto-agreement/

3. Georgian Newspaper - Civil Georgia "Georgia-Russia WTO Deal in Details", published November 18, 2011. Available at https://old.civil.ge/eng/article.php?id=24158 [Accessed: July 30, 2020].

4. The Legislative Herald of Georgia - "The Agreement between the Government of Georgia and the Government of the Russian Federation on the Basic Principles for a Mechanism of Customs Administration and Monitoring of Trade in Goods", 09/11/2011. Available at https:// www.matsne.gov.ge/ka/document/view/1512898?publication=0 [Accessed: July 30, 2020].

5. Georgian Public Information Database. Available at http://www.opendata.ge/ka/preview/52734 [Accessed: July 30, 2020].

6. Georgian English language newspaper - Georgia Today “Tbilisi Signs Contract with Swiss Company SGS over Georgia-Russia Cargo Deal”, published 20 December 2017. Available at http://georgiatoday.ge/news/8580/Tbilisi-Signs-Contract-with-Swiss-Company-SGS-overGeorgia-Russia-Cargo-Monitoring-Deal\%20 [Accessed: July 30, 2020].

7. United States government-funded organisation - Radio Free Europe/Radio Liberty "Georgia: Russia Threatens To Ban Wine Imports”, March 30, 2006. Available at https://www.rferl. org/a/1067256.html [Accessed: July 30, 2020].

8. EU-Georgia: Trade in Goods, published 22 April, 2020. Available at https:/ec.europa.eu/trade/ policy/countries-and-regions/countries/georgia/ [Accessed: August 1, 2020]. 